\title{
EFFECTS OF PLANT GROWTH-PROMOTING RHIZOBACTERIUM (PGPR) AND ARBUSCULAR MYCORRHIZAL FUNGUS (AMF) ON ANTIOXIDANT ENZYME ACTIVITIES IN SALT-STRESSED BEAN (PHASEOLUS VULGARIS L.)
}

\author{
OMID YOUNESI ${ }^{1 *}$, ALI MORADI ${ }^{2}$ \\ ${ }^{1}$ University of Tehran, Tehran \\ ${ }^{2}$ Yasouj University, Yasouj
}

YOUNESI, O. - MORADI, A.: Effects of plant growth-promoting rhizobacterium (PGPR) and arbuscular mycorrhizal fungus (AMF) on antioxidant enzyme activities in salt-stressed bean (Phaseolus vulgaris L.). Agriculture (Pol'nohospodárstvo), vol. 60, 2014, no. 1, pp. 11-21.

Plant Growth-Promoting Rhizobacterium (PGPR) represents a wide variety of soil bacteria that, when grown in association with a host plant, result in stimulation of growth of their host. The aim of this study was to investigate the influence of inoculation with a PGPR, Pseudomonas fluorescence, alone or in combination with an arbuscular mycorrhizal fungus, Glomus mosseae (Nicol. \& Gerd.), on antioxidant enzyme activities (catalase (CAT) and peroxidase $(\mathrm{POX})$ ), phosphatase activity, solutes accumulation, growth and minerals nutrient uptake in shoots of bean (Phaseolus vulgaris L.) affected by three levels of salt stress. Salinity decreased bean growth, regardless of the biological treatment and the salt stress level. The plants inoculated with $P$. fluorescence had significantly greater shoot biomass than the control plants at all salini- ty levels, whereas the mycorrhizal inoculation treatments were only effective in increasing shoot biomass at a low salinity level. The plants inoculated with P. fluorescence presented higher concentrations of shoots' $\mathrm{K}^{+}$and lower concentrations of shoots' $\mathrm{Na}^{+}$under high salt conditions. Salt stress increased shoots' proline concentration, particularly in plants inoculated with the PGPR. Increasing salinity stress raised significantly the antioxidant enzyme activities, including those of total POX and CAT, of bean shoots compared with their corresponding nonstressed plants. The PGPR strain induced a higher increase in these antioxidant enzymes in response to severe salinity. Inoculation with selected PGPR could serve as a useful tool for alleviating salinity stress in salt-sensitive plants.

Key words: arbuscular mycorrhizal fungi, bean, plant growth-promoting rhizobacterium, salinity

Saline soils and saline irrigation constitute a serious production problem for vegetable crops. Saline conditions are known to suppress plant growth, particularly in arid and semiarid areas (Parida \& Das 2005). Common bean (Phaseolus vulgaris L.) in a symbiotic association with Rhizobium leguminosarum bv. phaseoli can fix atmospheric nitrogen and represents one of the world's most important sources of dietary protein (Hantngston et al. 1986). Common bean growth is sensitive to salinity (Hantngston et al. 1986). Salt induces osmotic stress by limiting absorption of water from soil and ionic stress resulting from high concentrations of potentially toxic salt ions within plant cells. Salt stress is also linked to an oxidative stress as a consequence of the generation of reactive oxygen species, such as superoxide ion, hydrogen peroxide and hydroxyl radicals, which are detrimental to plant survival under salt stress. Salt-stressed plants display a complex oxidative defence strategy, with catalase (CAT) and peroxidise (POX) enzymes being involved in scavenging of the hydrogen peroxide generated in

Omid Younesi (*Corresponding author), Ph.D. of plant physiology, College of Agriculture \& Natural Resources, University of Tehran, Tehran, Iran. E-mail: omidyounesi@gmail.com

Ali Moradi, Assistant Professor, Department of Agronomy and Plant Breeding, Faculty of Agriculture, Yasouj University, Yasouj, Iran 
response to oxidative stress. Saline stress is also known to affect many physiological activities related to the accumulation of ions and osmolytes such as proline (Lee et al. 2008). The accumulation of these compounds plays a major role in the process of osmotic adjustment, limiting water loss and ion toxicity. Biochemical alterations in plants due to salt stress may affect the nutritional balance and consequently growth and development.

The use of plant growth-promoting bacteria (PGPR) and symbiotic microorganisms, especially arbuscular mycorrhizal (AM) fungi, may prove useful in developing strategies to facilitate plant growth in saline soils. For example, Glick et al. (1998) showed that under different stresses using PGPR such as Pseudomonas fluorescence can alleviate the adverse effects of stress on plant growth. It has been indicated that some PGPR are able to produce polysaccharide products, binding $\mathrm{Na}^{+}$in the root zone and hence alleviating the effects of salt stress on plant and enhancing microbial growth and activities (Tank \& Saraf 2010). Many studies have demonstrated that inoculation with AM fungi improves growth of plants under salt stress (Sharifi et al. 2007). The improved growth of AM plants has been attributed to enhanced nutrient uptake, particularly of $\mathrm{N}$ and $\mathrm{P}$ and subsequent increased growth (Jeffries et al. 2003). However, in some cases, plant salt tolerance was not related to $\mathrm{P}$ concentration (Ruiz-Lozano \& Azcón 2000). Thus, it has been proposed that salt-tolerance mechanisms, such as enhanced osmotic adjustment and reduced oxidative damage or improved nutritional status, can explain the contribution of AM symbioses to the salinity resistance of host plants (Augé 2001).

In this study, we hypothesise that inoculation with P. fluorescence and Glomus mosseae, alone or in combination, can induce salinity tolerance to bean and such tolerance is correlated with changes in antioxidant enzyme activity (CAT and POX activities), accumulation of solutes (proline and soluble sugars) and mineral nutrient uptake such as $\mathrm{P}$.

\section{MATERIALS AND METHODS}

The used soil for pots was collected from an uncultivated site located in Qom province, Iran. The basic soil properties were as follows: organic matter content $1.08 \%$, total $\mathrm{N} 0.062 \%$, total K $740.8 \mathrm{mg} / \mathrm{kg}$, total P $10.90 \mathrm{mg} / \mathrm{kg}$, available $\mathrm{P}\left(\mathrm{NaHCO}_{3}\right.$-extractable) $2.78 \mathrm{mg} / \mathrm{kg}$, water-soluble $\mathrm{K} 13.43 \mathrm{mg} / \mathrm{kg}$ and electrical conductivity $8.1 \mathrm{dS} / \mathrm{m}$.

The plant used in the experiment was bean (Phaseolus vulgaris L.). Seeds of bean were grown for 10 days in peat substrate under nursery conditions, without any fertilisation treatment.

\section{Microorganisms}

The mycorrhizal fungi used were obtained from the Institute of Soil and Water Research, Karaj, Iran. G. mosseae species was multiplied in pots using a mixture of sterile sepiolite/vermiculite (1:1, v:v) as growing substrate and Sorghum sp. as host plant. Trap cultures were maintained under greenhouse controlled conditions for 4 months. AM fungal inoculum consisted of a mixture of rhizospheric soil from the trap cultures containing spores, hyphae and mycorrhizal root fragments and was stored in polyethylene bags at $5^{\circ} \mathrm{C}$. The inoculum was subjected to a most probable number test (Sieverding 1991) to determine potential infectivity and equalise application doses. Sources of inoculum had a potential infectivity of about 35 infective propagules/g inoculum.

P. fluorescence was isolated from field soil located in Qom province, Iran, and was grown in liquid Tryptic Soy Broth medium at $30^{\circ} \mathrm{C}$. The bacterial culture was centrifuged at $4000 \mathrm{rpm}$ for $5 \mathrm{~min}$ at $2^{\circ} \mathrm{C}$ and the sediment was re-suspended in sterilised tap water. The bacterial suspension contained $10^{9}$ colony forming units $/ \mathrm{ml}$.

\section{Microbial inoculation and salt stress treatments}

The experiment was arranged as a factorial in completely randomised design with two factors and 3-fold replications. The first factor had four levels: control soil, soil inoculated with the AM fungus (AMF) G. mosseae, soil inoculated with the bacteria $P$. fluorescence, and a combination of soil inoculated with the bacteria $P$. fluorescence and with $G$. mosse$a e$. The second factor had three levels of salt stress: non-salt stress, moderate salt stress and severe salt stress.

An amount of $700 \mathrm{~g}$ of substrate consisting of soil and vermiculite at a ratio of 2:1 (v:v) sterilised by autoclaving at $105^{\circ} \mathrm{C}$ for $60 \mathrm{~min}$ in three consec- 
utive days was placed in 1-1 pots. Bean seedlings were transplanted to the pots (three per pot). The AM inoculum was mixed with the potting substrate at a rate of $5 \%(\mathrm{v} / \mathrm{v})$. The same amount of the autoclaved inoculum was added to non-AM plants, supplemented with a filtrate (Whatman no. 1 paper) of the culture, to provide the microbial populations accompanying the mycorrhizal fungi. P. fluorescence was inoculated two times during the growth period. The dose of inoculum applied corresponded to $10^{10}$ colony forming units per plant. Two concentrations ( 2 and $4 \mathrm{~g} \mathrm{NaCl} / \mathrm{kg}$ soil) of saline solution were applied to the saline pots. To avoid osmotic shock, the $\mathrm{NaCl}$ concentration was gradually increased for four consecutive days until the desired concentration was attained. A plastic bag was put underneath each pot to collect excess water due to drainage. This water was reapplied to the respective pot. All seedlings were grown for 4 weeks without any fertiliser treatment. At the end of experiment, the electrical conductivity of the non-saline pots and the pots cultivated under medium and high salinity levels was about $0.340,0.620$ and $0.920 \mathrm{dS} / \mathrm{m}$, respectively. The experiment was conducted in a greenhouse (average temperature ranged from 20 to $25^{\circ} \mathrm{C}$ and the relative humidity from 70 to $80 \%$ ). Midday photosynthetically active radiation averaged $260 \mathrm{E} / \mathrm{m}^{2} / \mathrm{s}$.

\section{Plant analyses}

One month after planting, two plants per treatment were harvested. The roots were washed free from soil under a stream of cold tap water and fresh and dry $\left(105^{\circ} \mathrm{C}, 5 \mathrm{~h}\right)$ weights of shoots and roots were recorded. Plant tissues were ground before chemical analysis. The foliar contents of phosphorus were determined, after digestion in nitric-perchloric acid (5:3) for $6 \mathrm{~h}$, by colorimetry (Murphy \& Riley 1962) and the plant K was estimated by flame photometry. The $\mathrm{N}$ concentration was determined by colorimetry after the Kjeldahl digestion.

Roots were sub-sampled in three 2 -cm cross-sections of the upper, middle and lower root system. To assess colonisation, roots were cleared with $10 \%$ $\mathrm{KOH}$ and stained with $0.05 \%$ trypan blue (Phillips $\&$ Hayman 1970). The percentage of root length colonised by AM fungi was calculated by the gridline intersect method (Giovannetti \& Mosse 1980). Positive counts for AM colonisation included the pres- ence of vesicles, arbuscules or typical mycelium within the roots.

Acid phosphatase activity was determined using p-nitrophenyl phosphate disodium $(0.115 \mathrm{M})$ as substrate. An amount of $2 \mathrm{ml}$ of $0.5 \mathrm{M}$ sodium acetate buffer at pH 5.5 using acetic acid and $0.5 \mathrm{ml}$ of substrate were added to $100 \mathrm{mg}$ of fresh root tissue and incubated at $37^{\circ} \mathrm{C}$ for $90 \mathrm{~min}$. The reaction was stopped by cooling at $2^{\circ} \mathrm{C}$ for $30 \mathrm{~min}$. Then, $0.5 \mathrm{ml}$ of $0.5 \mathrm{M} \mathrm{CaCl}_{2}$ and $2 \mathrm{ml}$ of $0.5 \mathrm{M} \mathrm{NaOH}$ were added, and the mixture was centrifuged at $4,000 \mathrm{rpm}$ for $5 \mathrm{~min}$. The p-nitrophenol formed was determined by spectrophotometry at $398 \mathrm{~nm}$ (Tabatabai \& Bremner 1969). Controls were made in the same way, although the substrate was added after incubation.

\section{Proline and total soluble sugars}

Free proline and total soluble sugars were extracted from $1 \mathrm{~g}$ of fresh shoots (Bligh \& Dyer 1959). The methanolic phase was used for the quantification of both substances. Proline was estimated by spectrophotometric analysis at $515 \mathrm{~nm}$ of the ninhydrin reaction, according to Bates et al. (1973). Soluble sugars were analysed by $0.1 \mathrm{ml}$ of the alcoholic extract reacting with $3 \mathrm{ml}$ freshly prepared anthrone $(200 \mathrm{mg}$ anthrone $+100 \mathrm{ml} \mathrm{72 \%} \mathrm{(w:w)}$ $\mathrm{H}_{2} \mathrm{SO}_{4}$ ) and placed in a boiling water bath for 10 min according to Irigoyen et al. (1992). After cooling, the absorbance at $620 \mathrm{~nm}$ was determined in a spectrophotometer. The calibration curve was made using glucose in the range of $20-400 \mu \mathrm{g} / \mathrm{ml}$.

\section{Measurement of CAT and POX activity}

All operations were performed at $4{ }^{\circ} \mathrm{C}$. Shoots $(2 \mathrm{~g})$ were homogenised with a mortar and pestle in $4 \mathrm{ml}$ of ice-cold $50 \mathrm{mM}$ Tris-acetate buffer $\mathrm{pH}$ 6.0 , containing $0.1 \mathrm{mM}$ ethylenediaminete-traacetic acid, $5 \mathrm{~m}$ Mcysteine, 2\% (w/v) polyvinylpyrrolidone, $0.1 \mathrm{mM}$ phenylmethylsulphonyl fluoride and $0.2 \%(\mathrm{v} / \mathrm{v})$ Triton $\mathrm{X}-100$. The homogenate was centrifuged at $14,000 \times \mathrm{g}$ for $20 \mathrm{~min}$ and the supernatant fraction was filtered through Sephadex G-25 columns (NAP, Pharmacia Biotech AB, Uppsala, Sweden), equilibrated with the same buffer used for the homogenisation.

CAT activity was determined at $25^{\circ} \mathrm{C}$ according to Aebi (1984). The reaction mixture contained $10 \mathrm{mM} \mathrm{H}_{2} \mathrm{O}_{2}$ in a $50 \mathrm{mM}$ phosphate buffer $\mathrm{pH}$ 7.0, and $100 \mu \mathrm{l}$ of leaf enzyme extract in a total volume 
of $3 \mathrm{ml}$. CAT activity was estimated by decrease in absorbance of $\mathrm{H}_{2} \mathrm{O}_{2}$ at $240 \mathrm{~nm}$. Total POX was determined in assays containing $50 \mathrm{~mm}$ Tris-acetate buffer ( $\mathrm{pH} 5.0$ ) and $0.5 \mathrm{~mm} \mathrm{H}_{2} \mathrm{O}_{2}$, using $1.0 \mathrm{~mm}$ 4-methoxynaphtol as electron donor $\left(\mathrm{E}_{595}=21,600\right.$ $\mathrm{m} / \mathrm{cm}$; Ros-Barceló 1998). The reaction was initiated by adding enzyme. Controls were carried out in the absence of $\mathrm{H}_{2} \mathrm{O}_{2}$.

\section{Statistical analysis}

Data were log transformed to achieve normality. Microbial inoculation, salinity level and their interaction effects on measured variables were tested by a two-way analysis of variance and comparisons among means were made using Dunkan's test calculated at $P<0.05$. Statistical procedures were carried out with the software package SPSS 10.0 for Windows.

\section{RESULTS}

Growth, shoot water content, nutrient assimilation and mycorrhizal colonisation

The data revealed significant $(P \leq 0.01)$ effect of salinity and microbial inoculation on shoot dry weight of bean (Table 1). Interactions among salinity $\times$ microbial treatments were also significant $(P \leq 0.05)$. Salinity decreased the dry weight of the shoots and roots for all bean plants (Table 2). The plants inoculated with $P$. fluorescence had significantly greater shoot biomass than the control plants at both salinity levels, whereas the mycorrhizal inoculation treatments only were effective in increasing shoot biomass at the medium salinity level. Under non-saline conditions, shoot dry weight of bean was increased by the inoculation with $P$. fluorescence, while no significant effect was found with the mycorrhizal inoculation treatments (Table 2). The mycorrhizal and bacterial inoculation produced similar increases in plant growth. Neither of the microbial treatments had an effect on the root biomass (Table 1).

Statistical analysis of the data showed significant $(P \leq 0.01)$ effect of salinity and microbial treatments on shoot water content of bean (Table 1). Leaf hydration was changed by the salt and microbial treatments. The bacterial inoculation increased significantly $(P \leq 0.01)$ the shoot water content in the non-salinised plants. At the highest salinity level, the water content was higher in shoots of plants treated with $P$. fluorescence or G. mosseae (Table 2).

In non-salinised plants, mycorrhizal inoculation treatment produced active colonisation in root systems of bean seedlings. The level of colonisation in roots of mycorrhizal plants was not affected by bacterial inoculation but decreased significantly $(P \leq 0.05)$ with increasing $\mathrm{NaCl}$ concentration (Table 1). The results indicate that different levels of salinity had inhibitory effects on mycorrhizal colonisation. High mycorrhizal colonisation was observed at the control condition (non-salt stress) (Table 2).

The assayed salinity and microbial inoculations significantly affected $(P \leq 0.01)$ the foliar $\mathrm{N}$ and $\mathrm{P}$ concentrations of bean plants (Table 1). Interactions among salinity $\times$ microbial treatments were also significant $(P \leq 0.05)$. A $22.38 \%$ and $47.55 \%$ reduction in foliar $\mathrm{N}$ concentration was caused by medium and severe salinity levels as compared with the control (non-salt stress), respectively (Table 3 ). The mycorrhizal inoculation treatment in combination with $P$. fluorescence was the most effective treatment for increasing the foliar $\mathrm{N}$ concentration. Also, the highest foliar concentrations of phosphorus were seen in the plants inoculated with G. mosseae, alone or in combination with $P$. fluorescence. At the medium salinity level, G. mosseae-colonised plants showed the highest concentration of foliar P.

Data regarding $\mathrm{Na}, \mathrm{K}$ and $\mathrm{Ca}$ concentrations showed significant effect of salinity $(P \leq 0.01)$ and microbial $(P \leq 0.05)$ treatments on $\mathrm{Na}, \mathrm{K}$ and $\mathrm{Ca}$ contents of beans (Table 1). Interactions among salinity $\times$ microbial treatments were also significant $(P \leq 0.05)$. Salinity increased the foliar, $\mathrm{Na}$ concentration and decreased the foliar $\mathrm{K}$ and $\mathrm{Ca}$ concentrations in bean plants (Table 3). The increased $\mathrm{Na}$ due to salt stress was higher in the control plants than in the plants treated with P. fluorescence or AM fungi. P. fluorescence- and $G$. mosseae-colonised plants presented the highest concentrations of foliar $\mathrm{K}$ and lowest concentrations of foliar $\mathrm{Na}$ under high salt-stress conditions. 


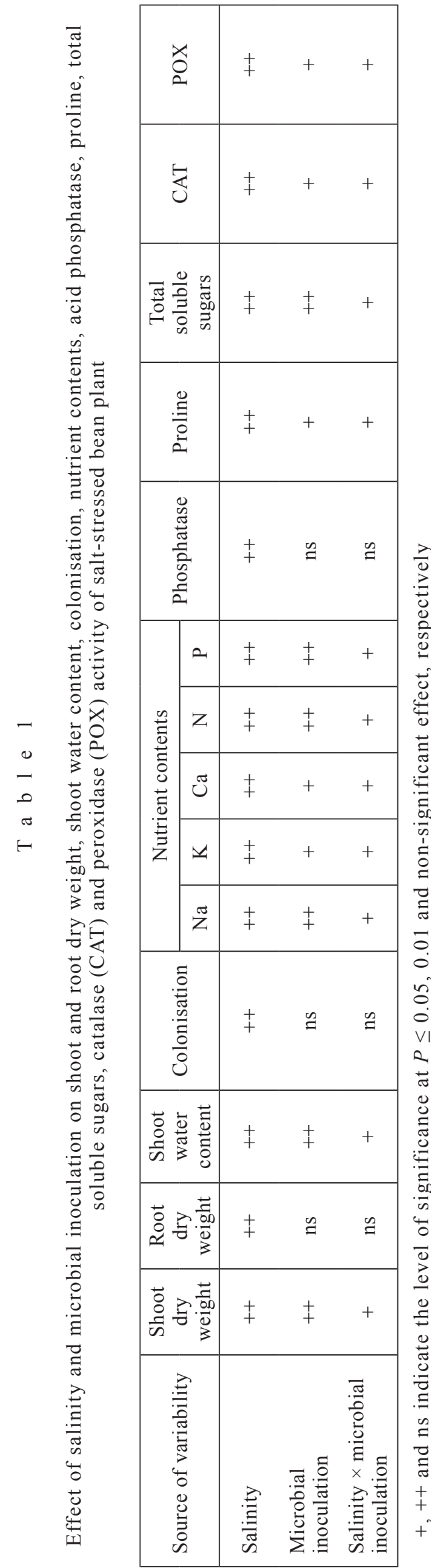

Phosphatase activity, proline and solute accumulation

Statistical analysis of the data showed significant $(P \leq 0.01)$ effect of salinity on phosphatase activity of bean (Table 1). But neither bacterial nor mycorrhizal inoculation had any significant $(P \geq 0.05)$ effect on the phosphatase activity of non-salinised plants (Table 1). Phosphatase activity in roots of the $P$. fluorescence-inoculated and control plants was increased significantly at the medium salinity level (Table 4).

Proline concentrations increased significantly $(P \leq 0.01)$ as a consequence of salinity (Table 1$)$. Statistical analyses of the data revealed that no significant $(P \geq 0.05)$ differences among the different treatments were found for proline accumulation in bean shoots under non-saline conditions (Table 4). Proline accumulation was considerably less for mycorrhizal plants than non-mycorrhizal plants at the medium salinity level (Table 4). In the case of P. fluorescence-inoculated plants, the increase in proline concentration was higher than control plants at the highest salinity level. At medium and high salinity levels, plants co-inoculated with Pseudomonas and AMF showed $11 \%$ and $21 \%$ greater proline than the control plant, respectively.

Data revealed significant $(P \leq 0.01)$ effect of salinity and microbial treatments on soluble sugar accumulation of bean (Table 1). Interactions between salinity $\times$ microbial treatments were also significant $(P \leq 0.05)$. Salt stress decreased sugar accumulation in all plants (Table 4). Under high salt stress conditions, the control plants accumulated the lowest concentration of total soluble sugars. Under non-saline conditions, the inoculation with the microbial inoculation caused differences in the total soluble sugar accumulation when compared with the control plants. At the medium and high salinity levels, only plants co-inoculated with Pseudomonas and AMF had significant effect on soluble sugar accumulation and showed $63.67 \%$ and $95.57 \%$ greater proline as compared with the control plants.

\section{Antioxidant enzyme activities}

Statistical analysis of the data showed significant $(P \leq 0.01)$ effect of salinity and microbial treatments on antioxidant enzyme activities of bean (Table 1). Interactions among salinity $\times$ microbial treatments 
$\mathrm{T}$ a

Effect of inoculation with Pseudomonas fluorescence and Glomus mosseae on shoot and root dry biomass, shoot water content and colonisation of bean seedlings grown at three levels of salinity

\begin{tabular}{|c|c|c|c|c|}
\hline Treatment & $\begin{array}{c}\text { Shoot dry } \\
\text { biomass [g dw] }\end{array}$ & $\begin{array}{c}\text { Root dry } \\
\text { biomass } \\
{[\mathrm{g} \mathrm{dw}]}\end{array}$ & $\begin{array}{l}\text { Shoot water } \\
\text { content }[\%]\end{array}$ & $\begin{array}{c}\text { Colonisation } \\
{[\%]}\end{array}$ \\
\hline \multicolumn{5}{|c|}{ Without NaCl } \\
\hline Control & 1.23 & 0.65 & 64.00 & 0.00 \\
\hline P. fluorescence & 1.60 & 0.65 & 82.50 & 0.00 \\
\hline G. mosseae & 1.40 & 0.72 & 80.00 & 65.60 \\
\hline P. fluorescence + G. mosseae & 1.67 & 0.68 & 84.40 & 66.20 \\
\hline \multicolumn{5}{|c|}{$2 \mathrm{~g} \mathrm{NaCl} / \mathrm{kg}$ soil } \\
\hline Control & 0.80 & 0.52 & 60.00 & 0.00 \\
\hline P. fluorescence & 1.23 & 0.55 & 81.10 & 0.00 \\
\hline G. mosseae & 1.15 & 0.60 & 78.40 & 48.20 \\
\hline P. fluorescence + G. mosseae & 1.35 & 0.61 & 83.80 & 48.50 \\
\hline \multicolumn{5}{|c|}{$4 \mathrm{~g} \mathrm{NaCl} / \mathrm{kg}$ soil } \\
\hline Control & 0.63 & 0.38 & 58.70 & 0.00 \\
\hline P. fluorescence & 1.17 & 0.45 & 78.30 & 0.00 \\
\hline G. mosseae & 1.05 & 0.47 & 63.50 & 35.00 \\
\hline P. fluorescence + G. mosseae & 1.30 & 0.45 & 80.20 & 36.30 \\
\hline $\mathrm{LSD}_{0.05}$ & 0.14 & 0.09 & 5.26 & 9.34 \\
\hline
\end{tabular}

$\mathrm{T}$ a

Effect of inoculation with Pseudomonas fluorescence and Glomus mosseae on potassium, sodium, calcium and phosphorus content of bean seedlings grown at three levels of salinity

\begin{tabular}{|c|c|c|c|c|c|}
\hline Treatment & $\mathrm{N}[\mathrm{mg} / \mathrm{g}]$ & $\mathrm{P}[\mathrm{mg} / \mathrm{g}]$ & $\mathrm{K}[\mathrm{mg} / \mathrm{g}]$ & $\mathrm{Na}[\mathrm{mg} / \mathrm{g}]$ & $\mathrm{Ca}[\mathrm{mg} / \mathrm{kg}]$ \\
\hline \multicolumn{6}{|c|}{ Without NaCl } \\
\hline Control & 14.30 & 1.80 & 41.30 & 5.33 & 3.87 \\
\hline P. fluorescence & 17.60 & 2.85 & 46.60 & 3.27 & 4.30 \\
\hline G. mosseae & 16.50 & 2.90 & 51.34 & 5.64 & 5.30 \\
\hline P. fluorescence + G. mosseae & 18.00 & 3.50 & 56.28 & 3.12 & 5.85 \\
\hline \multicolumn{6}{|c|}{$2 \mathrm{~g} \mathrm{NaCl} / \mathrm{kg}$ soil } \\
\hline Control & 11.10 & 1.10 & 36.23 & 7.35 & 2.63 \\
\hline P. fluorescence & 16.90 & 2.55 & 41.50 & 4.87 & 3.80 \\
\hline G. mosseae & 16.20 & 3.23 & 45.67 & 6.80 & 4.90 \\
\hline P. fluorescence $+G$. mosseae & 17.00 & 2.80 & 48.81 & 4.38 & 5.13 \\
\hline \multicolumn{6}{|c|}{$4 \mathrm{~g} \mathrm{NaCl} / \mathrm{kg}$ soil } \\
\hline Control & 7.50 & 0.90 & 24.20 & 9.16 & 1.88 \\
\hline P. fluorescence & 12.30 & 1.38 & 36.23 & 5.65 & 3.17 \\
\hline G. mosseae & 10.20 & 2.10 & 34.47 & 7.55 & 3.78 \\
\hline P. fluorescence + G. mosseae & 14.70 & 2.53 & 38.43 & 5.30 & 4.26 \\
\hline $\mathrm{LSD}_{0.05}$ & 2.40 & 0.98 & 2.16 & 1.72 & 1.04 \\
\hline
\end{tabular}


were also significant $(P \leq 0.05)$. Salinity notably increased the specific total POX and CAT activities in the non-inoculated and inoculated plants (Table 5). The inoculation with P. fluorescence and AMF increased CAT and POX activities in shoots of non-salinised bean plants, as shown in Table 5 . The total POX activity of plants treated with P. fluorescence in combination with the AM fungi was increased by all salt levels. At the high salinity level, POX and CAT activities were, on average, 3- and 1.65-fold higher than the control plant, respectively.

\section{DISCUSSION}

Salinity adversely affected the growth of bean, regardless of the biological treatment and the saltstress level. However, when the plants were inoculated with an AMF or a PGPR, the extent of growth suppression was decreased and these treated plants had greater dry weights than untreated plants. Our results show that the AM fungi assayed stimulated significantly the growth of bean plants only under moderately saline conditions, while inoculation with $P$. fluorescence increased plant biomass even under severely saline conditions. On the other hand, the effect of dual inoculation with PGPR and AM fungi on shoot biomass of bean was similar to that of PGPR colonisation alone. These observations clearly suggest that the selected microorganisms can differentially alleviate some of the deleterious effects of salt stress.

Increased salt concentration decreases the osmotic potential of a growth medium, thus reducing the water availability. The use of water content is a good indicator of water stress (Mayak et al. 2004). In the control plants, leaf water content decreased as the external salt concentration increased. However, plants inoculated with $P$. fluorescence were more hydrated than the control plants under saline conditions. These results demonstrated that the bacterial treatment influenced the extent of water stress and that $P$. fluorescence efficiently protected the host plants against the detrimental effects of salt. Greater hydration induced by the PGPR strain might be attributable to increased water use efficiency and/or

$\mathrm{T}$ a

Effect of inoculation with Pseudomonas fluorescence and Glomus mosseae on acid phosphatase, proline and total soluble sugars of bean seedlings grown at three levels of salinity

\begin{tabular}{|c|c|c|c|}
\hline Treatment & $\begin{array}{l}\text { Acid phosphatase } \\
{[\mu \mathrm{mol} \text { PNP* g/h] }}\end{array}$ & Proline $[\mu \mathrm{mol} / \mathrm{g} \mathrm{FW}]$ & $\begin{array}{c}\text { Total soluble sugars } \\
{[\mathrm{mg} / \mathrm{g} \mathrm{FW}]}\end{array}$ \\
\hline \multicolumn{4}{|c|}{ Without NaCl } \\
\hline Control & 28 & 5.0 & 30.5 \\
\hline P. fluorescence & 30 & 5.5 & 40.0 \\
\hline G. mosseae & 30 & 5.1 & 43.3 \\
\hline P. fluorescence + G. mosseae & 31 & 5.5 & 47.6 \\
\hline \multicolumn{4}{|c|}{$2 \mathrm{~g} \mathrm{NaCl} / \mathrm{kg}$ soil } \\
\hline Control & 34 & 9.6 & 22.3 \\
\hline P. fluorescence & 46 & 12.8 & 28.2 \\
\hline G. mosseae & 42 & 6.7 & 24.4 \\
\hline P. fluorescence + G. mosseae & 39 & 10.7 & 36.5 \\
\hline \multicolumn{4}{|c|}{$4 \mathrm{~g} \mathrm{NaCl} / \mathrm{kg}$ soil } \\
\hline Control & 35 & 11.8 & 11.3 \\
\hline P. fluorescence & 44 & 14.8 & 16.2 \\
\hline G. mosseae & 43 & 12.6 & 13.0 \\
\hline P. fluorescence + G. mosseae & 53 & 14.4 & 22.1 \\
\hline $\mathrm{LSD}_{0.05}$ & 12 & 3.16 & 8.87 \\
\hline
\end{tabular}

*p-nitrophenol 
enzymatic lowering of plant ethylene concentrations thereby decreasing the ethylene inhibition of seedling root biomass (Saravanakumar \& Samiyappan 2007). The root biomass of control plants was decreased as a consequence of salinity, while those of inoculated plants was not decreased at the medium salinity level and suffered a lesser reduction at the highest level.

The increased shoot biomass of seedlings inoculated with AM fungi could be partly related to the increase in water uptake that a mycorrhizal fungus provides under saline conditions (Ruiz-Lozano \& Azcón 1996): the higher shoot water content in plants inoculated with G. mosseae supports this possibility. Nutritional mechanisms may have played a role in the differential modulation of host water status by the different AMF species. Improved nutritional status can lead to specific stimulation of photosynthetic capacity over stomatal conductance, which, in turn, influences positively the plant water status (Querejeta et al. 2003). In particular, the protection of mycorrhizal plants against salt stress was related to the effect that the added endophytes had on increasing P uptake. The concentration of foliar
$\mathrm{P}$ in mycorrhizal plants was particularly increased under moderately saline conditions. Enhanced P nutrition is considered as one of the major mechanisms by which AMF can improve the water status of their host plants (Augé 2001). Non-nutritional mechanisms by which AMF can also improve the water status of their host plants include hormonal signalling, osmotic adjustment, changes in root hydraulic conductivity, direct contributions of extraradical hyphae to water uptake and changes in the moisture characteristics of rhizosphere soil (Augé 2001). It has been hypothesised that mycorrhizae can alter the morphology of the root system, yielding a more extensive absorbing area, which may be considered a mechanism of salinity tolerance (Ibrahim et al. 1990). Likewise, mycorrhizae are known to increase the xylem pressure potential by increasing root biomass and therefore improving water uptake (Augé 2001). It is worth noting that the root biomass of G. mosseae-colonised plants was about double that of the control plants under moderately saline conditions.

In many plants, salt stress has been shown to affect carbohydrate partitioning and metabolism,

$\mathrm{T} \quad \mathrm{a} \quad \mathrm{b} \quad 1 \quad \mathrm{e} \quad 5$

Effect of inoculation with Pseudomonas fluorescence and Glomus mosseae on peroxidase (POX) and catalase (CAT) activities of bean seedlings grown at three levels of salinity

\begin{tabular}{|c|c|c|}
\hline Treatment & $\begin{array}{c}\text { POX } \\
{[\mu \mathrm{mol} / \mathrm{min} / \mathrm{g} \mathrm{FW}]}\end{array}$ & $\begin{array}{c}\text { CAT } \\
{[\mu \mathrm{mol} / \mathrm{min} / \mathrm{g} \mathrm{FW}]}\end{array}$ \\
\hline \multicolumn{3}{|c|}{ Without $\mathrm{NaCl}$} \\
\hline Control & 136 & 31 \\
\hline P. fluorescence & 387 & 35 \\
\hline G. mosseae & 300 & 32 \\
\hline P. fluorescence + G. mosseae & 410 & 36 \\
\hline \multicolumn{3}{|c|}{$2 \mathrm{~g} \mathrm{NaCl} / \mathrm{kg}$ soil } \\
\hline Control & 143 & 35 \\
\hline P. fluorescence & 420 & 41 \\
\hline G. mosseae & 385 & 38 \\
\hline P. fluorescence + G. mosseae & 462 & 44 \\
\hline \multicolumn{3}{|c|}{$4 \mathrm{~g} \mathrm{NaCl} / \mathrm{kg}$ soil } \\
\hline Control & 152 & 38 \\
\hline P. fluorescence & 438 & 51 \\
\hline G. mosseae & 418 & 46 \\
\hline P. fluorescence + G. mosseae & 480 & 63 \\
\hline $\mathrm{LSD}_{0.05}$ & 64 & 18 \\
\hline
\end{tabular}


leading to the synthesis of new compounds (Sharma et al. 1990). In particular, various solutes have been shown to accumulate during salinity. Their accumulation might be of importance for the adjustment of the cellular water potential under conditions of reduced water availability, and they can act as scavengers of reactive oxygen species. In plants exposed to salinity, the total non-structural carbohydrate content in the shoots was reduced significantly compared with plants not exposed to salinity. This could indicate that salinity induces a preferential partitioning of carbohydrates to the roots, as demonstrated by Schellenbaum et al. (1998). The decrease in total soluble carbohydrates due to salinity could be related also to limited carbohydrate availability, as a consequence of a decline in photosynthesis (Goicoechea et al. 2005). The control plants presented the highest reductions in shoot total soluble sugars throughout the salt-stress experiment, which could indicate that these plants were less salt tolerant. The total soluble carbohydrates of plants inoculated with $P$. fluorescence and/or the AM fungi were not affected under moderate salinity.

In contrast to soluble carbohydrates, moderate and severe salinity increased shoot proline accumulation in non-mycorrhizal plants. A high level of proline enables the plants to maintain an osmotic balance when growing under low water potentials. It is reported that proline protects higher plants against salt/osmotic stresses, not only by adjusting osmotic pressure, but also by stabilising many functional units such as complex II electron transport, membranes and proteins and enzymes such as RUBISCO (Mäkelä et al. 2000). However, no changes in proline concentrations were observed in plants inoculated with the selected AM fungi in response to moderate salinity. This could indicate that moderate salinity affected to a lesser extent the mycorrhizal plants, so they accumulated less proline. The concentrations of proline are always not high enough to adjust the osmotic potential in some plants under stress (Hoque et al. 2007). In fact, the inhibition of growth of bean was higher in non-inoculated plants than in inoculated plants in spite of the fact that the levels of proline were similar for all plants under severe salinity. Thus, our data suggest that the accumulation of proline itself cannot confer salt tolerance in bean plants.
Salinity dominated by $\mathrm{Na}^{+}$and $\mathrm{Cl}^{-}$not only reduces $\mathrm{Ca}^{2+}$ and $\mathrm{K}^{+}$availability, but also reduces $\mathrm{Ca}^{2+}$ and $\mathrm{K}^{+}$mobility and transport to the growing parts of plants, affecting the quality of both vegetative and reproductive organs. Moreover, many studies have shown that high concentrations of $\mathrm{NaCl}$ in the soil solution may increase the ratios of $\mathrm{Na}^{+} / \mathrm{Ca}^{2+}$ and $\mathrm{Na}^{+} / \mathrm{K}^{+}$in plants, which would then be more susceptible to osmotic and specific ion injury as well as to nutritional disorders that result in reduced yield and quality (Sivritepe et al. 2003). Salt tolerance in plants has been related to their ability to decrease leaf osmotic potential, which has been linked to $\mathrm{Na}^{+}$and/or $\mathrm{Cl}^{-}$ion exclusion mechanisms or to the retention of salt ions in roots, preventing the accumulation of $\mathrm{Na}^{+}$and/or $\mathrm{Cl}^{-}$in the shoot. The results of this study show that salinity caused an increase in $\mathrm{Na}$ concentration and a decrease in $\mathrm{K}^{+}$and $\mathrm{Ca}^{2+}$ regardless of the microbiological treatment. However, both microbiological treatments reduced the $\mathrm{Na}^{+}$uptake of plants and/or increased the $\mathrm{K}^{+}$uptake, compared with the control plants under salt stress, thus increasing the $\mathrm{K}^{+}: \mathrm{Na}^{+}$ratio. Previous studies indicate that an increase in concentration of $\mathrm{K}^{+}$in plants under salt stress could ameliorate the deleterious effects of salinity on growth and yield (Giri et al. 2007). Potassium plays a key role in plant water stress tolerance and has been found to be the cationic solute responsible for stomatal movements in response to changes in bulk leaf water status (Caravaca et al. 2004). This means that the $P$. fluorescence strain and AM fungi could alleviate the effects of salinity stress in bean. Reduced $\mathrm{Na}$ concentration in bean plants exposed to salinity, due to AM inoculation, may have helped the plants prevent accumulation of cellular $\mathrm{Na}$ to a toxic concentration. There are several reports of lower $\mathrm{Na}^{+}$concentrations in AM plants, compared with non-AM plants, under salinity (Giri \& Mukerji 2004; Ashraf et al. 2004; Sharifi et al. 2007). In the case of P. fluorescence, this PGPR strain can produce exopolysaccharides that bind cations, including $\mathrm{Na}^{+}$(Kohler et al. 2006), thus decreasing the content of $\mathrm{Na}^{+}$available for plant uptake. We have shown the beneficial effect of this PGPR strain on soil aggregate stabilisation (Kohler et al. 2006). Previous studies have described a negative relationship between soil aggregation and percentage of $\mathrm{Na}^{+}$saturation in the ex- 
change complex (Lax et al. 1994). In this context, the reduced $\mathrm{Na}^{+}$concentrations recorded in shoots of $P$. fluorescence-colonised plants could be due to the lower percentage of exchangeable $\mathrm{Na}^{+}$in the soil cultivated with such plants. It has been indicated that salt stress affects the physiology and biochemistry of plant cells under in vitro and in vivo conditions. In this context, increased acid phosphatase has been reported in plants grown under salt stress (Duff et al. 1994). We have observed that moderate salinity enhanced the phosphatase activity of non-mycorrhizal bean plants. Ehsanpour and Amini (2003) also demonstrated that osmotic and salt stresses increase acid phosphatase activity in Medicago sativa. Acid phosphatase is known to act under stress by maintaining a certain level of inorganic phosphate in plant cells (Olmos \& Hellin 1997). The fact that mycorrhizal plants showed the highest levels of foliar P could explain why salinity did not affect the phosphatase activity of such plants. However, our results show that acid phosphatase did not play a role in responses of inoculated and non-inoculated lettuce to severe salinity.

Salt stress may induce a combination of negative effects on salt-sensitive plants including osmotic stress, ion toxicity and oxidative stress. The induction of antioxidant enzyme such as CAT and POX can be considered as one mechanism of salt tolerance in plants (Hernández et al. 2003). These antioxidant enzymes are involved in eliminating $\mathrm{H}_{2} \mathrm{O}_{2}$ from salt-stressed roots (Kim et al. 2005). CAT, which is localised in peroxisomes, decomposes hydrogen peroxide to water and molecular oxygen without consuming reductants and, thus, may provide plant cells with an energy-efficient mechanism to remove hydrogen peroxide (Scandalios et al. 1997). Hydrogen peroxide can be removed also by "non-specific" POX in the apoplast of lignifying tissues (Ros-Barceló et al. 2006), which use hydrogen peroxide as an electron donor to metabolise phenolic compounds. These latter enzymes are ubiquitous and are involved in various processes such as cell growth control and tolerance of environmental stress (Quiroga et al. 2000). Thus, decreased activity of POX can prevent or reduce lignification processes caused by salinity, thereby enabling continuity of water uptake through the cell walls (Yazici et al. 2007). Reduced CAT activity under stress conditions has been re- ported in other plants, such as sunflower (Mike et al. 1992); this reduction is parallel to a rise in the $\mathrm{H}_{2} \mathrm{O}_{2}$ content. Increasing salinity stress significantly increased the antioxidant enzyme activities of bean shoots, including those of POX and CAT, compared with their respective non-stressed controls. Remarkably, the PGPR strain induced a higher increase in these antioxidant enzymes in response to severe salinity. Based on these findings, a PGPR, P. fluorescence, was more effective than an $\mathrm{AMF}$ with respect to alleviating the negative effect of salinity on the growth of bean. Co-inoculation with PGPR and AMF had no additive effect on the plant growth. The contribution of the PGPR and AM fungi to plant salt tolerance was closely related to salinity avoidance mechanisms, including increased water uptake and restricted Na uptake. The protection of mycorrhizal plants against moderate salt stress was also related to the effect that the added endophytes had on increasing P uptake. Induction of antioxidant enzyme activities was involved in the ability of the PGPR strain to increase the tolerance of lettuce grown under severe salt stress. Therefore, inoculation with selected PGPR could serve as a useful tool for alleviating salinity stress in salt-sensitive plants.

\section{CONCLUSIONS}

The results of this study showed that both PGPR and AMF can modify salt stress in salt-stressed bean. It seems the positive effects of the microbial inoculation on tolerance of salt-stressed bean may be through improving reactive oxyradical scavenging system, and increasing osmotic adjustment compounds and mineral nutrient contents under salt stress conditions. Thus, inoculation with selected PGPR and AMF could serve as a useful tool for alleviating salinity stress in salt-sensitive plants.

\section{REFERENCES}

AEBI, H. 1984. Catalase in vitro. In Methods in Enzymology, vol. 105, pp. 121-126.

ASHRAF, M. - BERGE, S.H. - MAHMOOD, O.T. 2004. Inoculating wheat seedlings with exopolysaccharide-producing bacteria restricts sodium uptake and stimulates plant growth under salt stress. In Biology and 
Fertility of Soils, vol. 40, pp. 157-162. DOI 10.1007/ s00374-004-0766-y.

AUGÉ, R.M. 2001. Water relations, drought and vesicular-arbuscular mycorrhizal symbiosis. In Mycorrhiza, vol. 11 , no. 1 , pp. 3-42.

BATES, L.S. - WALDREN, R.P. - TEARE, I.D. 1973 Rapid determination of free proline for water stress studies. In Plant and Soil, vol. 39, no. 1, pp. 205-207.

BLIGH, E.G. - DYER, W.J. 1959. A rapid method of total lipid extraction and purification. In Canadian Journal of Biochemistry and Physiology, vol. 37, no. 8, pp. 911-917.

CARAVACA, F. - FIGUEROA, D. - BAREA, J.M. AZCÓN-AGUILAR, C. - ROLDÁN, A. 2004. Effect of mycorrhizal inoculation on the nutrient content, gas exchange and nitrate reductase activity of Retama sphaerocarpa and Olea europaea subsp. sylvestris under drought stress. In Journal of Plant Nutrition vol. 27, pp. 57-74. DOI:10.1081/PLN-120027547.

DUFF, S.M.G. - SARATH, G. - PLAXTON, W.C. - 1994. The role of acid phosphatases in plant phosphorus metabolism. In Physiology Plantarum, vol. 90, pp. 791-800. DOI: $10.1111 / \mathrm{j} .1399-3054.1994 . t b 02539 . x$.

EHSANPOUR, A.A. - AMINI, F. 2003. Effect of salt and drought stress on acid phosphatase activities in alfalfa (Medicago sativa L.) explants under in vitro culture. In African Journal of Biotechnology, vol. 2, pp. 133-135.

GIOVANNETTI, M. - MOSSE, B. 1980. An evaluation of techniques for measuring vesicular-arbuscular mycorrhizal infection in roots. In New Phytologist, vol. 84, no. 3, pp. 489-500. DOI: 10.1111/j.14698137.1980.tb04556.x.

GIRI, B. - KAPOOR, R. - MUKERJI, K.G. 2007. Improved tolerance of Acacia nilotica to salt stress by arbuscular mycorrhizal, Glomus fasciculatum may be partly related to elevated $\mathrm{K} / \mathrm{Na}$ ratios in root and shoot tissues. In Microbial Ecology, vol. 54, no. 4, pp. 753-760. DOI: 10.1007/s00248-007-9239-9.

GIRI, B. - MUKERJI, K.G. 2004. Mycorrhizal inoculant alleviates salt stress in Sesbania aegyptiaca and Sesbania grandiflora under field conditions: evidence for reduced sodium and improved magnesium uptake. In Mycorrhiza, vol. 14, pp. 307-312.

GLICK, B.R. - LIU, C. - GHOSH, S. - DUMBROF, E.B. - 1998. Early development of canola seedlings in the presence of the plant growth-promoting rhizobacterium Pseudomonas putida GR12-2. In Soil Biology and Biochemistry, vol. 29, no. 8, pp. 1233-1239.

GOICOECHEA, N. - MERINO, S. - SÁNCHEZ-DÍAZ, M. 2005. Arbuscular mycorrhizal fungi can contribute to maintain antioxidant and carbon metabolism in nodules of Anthyllis cytisoides L. subjected to drought. In Journal of Plant Physiology, vol. 162, no. 1, pp. 27-35. DOI:10.1016/j.jplph.2004.03.011.

HANTNGSTON, T.G. - SMITH, M.S. - THOMAS, G.W. - BLEVINS, R.L. -PEREZ, A. 1986. Responses of Phseolus vulgaris to inoculation with Rhizobium phaseoli under two tillage systems in the Dominican Republic. In Plant and Soil, vol. 95, pp. $77-85$
HERNANDEZ, J.A. - AGUILAR, A. - PORTILO, B. - LOPEZ-GOMEZ, E. - MATAIZ BENEYTO, J. GARCIALEGAZ, MF. 2003. The effect of calcium on the antioxidant enzymes from salt-treated loquat and anger plants. In Functional Plant Biology, vol. 30, pp. 1127-1137.

HOQUE, M.A. - OKUMA, E. - BANU, M.N.A. - NAKAMURA, Y. - SHIMOISHI, Y. - MURATA, Y. 2007. Exogenous proline mitigates the detrimental effects of salt stress more than exogenous betaine by increasing antioxidant enzyme activities. In Journal of Plant Physiology, vol. 164, no. 5, pp. 553-561. DOI:10.1016/j.jplph.2006.03.010.

IBRAHIM, M.A. - CAMPBELL, W.F. - RUPP, L.A. ALLEN, E.B. 1990. Effects of mycorrhizae on sorghum growth, photosynthesis, and stomatal conductance under drought conditions. In Arid Soil Research and Rehabilitation, vol. 4, pp. 99-107.

IRIGOYEN, J.J. - EMERICH, D.W. - SÁNCHEZ-DÍAZ, M. 1992. Water stress induced changes in concentrations of proline and total soluble sugars in nodulated alfalfa (Medicago sativa) plants. In Physiologia Plantarum, vol. 84, no. 1, pp. 55-60. DOI: 10.1111/ j.1399-3054.1992.tb08764.x.

JEFFRIES, P. - GIANINAZZI, S. - PEROTTO, S. TURNAU, K. - BAREA, J.M. 2003. The contribution of arbuscular mycorrhizal fungi in sustainable maintenance of plant health and soil fertility. In Biology and Fertility of Soils, vol. 37, no. 1, pp. 1-16. DOI: 10.1007/s00374-002-0546-5.

KIM, S.Y. - LIM, J.H. - PARK, M.R. - KIM, Y.J. PARK, T.I.I. - SEO, Y.W. - CHOI, K.G. - YUN, S.J. 2005. Enhanced antioxidant enzymes are associated with reduced hydrogen peroxide in barley roots under salt stress. In Journal of Biochemistry and Molekular Biology, vol. 38, pp. 218-224.

KOHLER, J. - CARAVACA, F. - CARRASCO, L. ROLDÁN, A. 2006. Contribution of Pseudomonas mendocina and Glomus intraradices to aggregates stabilisation and promotion of biological properties in rhizosphere soil of lettuce plants under field conditions. In Soil Use Management, vol. 22, no. 3, pp. 298-304. DOI: 10.1111/j.1475-2743.2006.00041.x. LAX, A. - DÍAZ, E. - CASTILlO, V. - ALBALADEJO, J. 1994. Reclamation of physical and chemical properties of a salinized soil by organic amendment. In Arid Soil Research and Rehabilitation, vol. 8, pp. 9-17.

LEE, G. - CARROW, R.N. - DUNCAN, R.R. - EITEMAN, M.A. - RIEGER, M.W. 2008. Synthesis of organic osmolytes and salt tolerance mechanisms in Paspalum vaginatum. In Environmental and Experimental Botany, vol. 63, no. 1-3, pp. 19-27. DOI:10.1016/j.envexpbot.2007.10.009.

MÄKELÄ, P. - KÄRKKÄINEN, J. - SOMERSALO, S. 2000. Effect of glycinebetaine on chloroplast ultrastructure, chlorophyll and protein content, and RuBPCO activities in tomato grown under drought or salinity. In Biologia Plantarum, vol. 43, no. 3, pp. 471-475. 
MAYAK, S. - TIROSH, T. - GLICK, B.R. - 2004. Plant growth-promoting bacteria confer resistance in tomato plants to salt stress. In Plant Physiology and Biochemistry, vol. 42 , no. 6 , pp. 565-572. DOI:10.1016/j. plaphy.2004.05.009.

MIKE, F. - QUARTACCI, M.G. - NAVARI-IZZO, F. 1992. Water stress and free radical mediated changes in sunflower seedlings. In Journal of Plant Physiology, vol. 139, no. 5, pp. 621-626.

MURPHY, J. - RILEY, J.P. - 1962. A modified single solution method for determination of phosphate in natural waters. In Analytica Chimica Acta, vol. 27, pp. 31-36.

OLMOS, E. - HELLIN, E. 1997. Cytochemical localization of ATPase plasma membrane and acid phosphatase by cerium based in a salt-adapted cell line of Pisum sativum. In Journal of Experimental Botany, vol. 48, pp. 1529-1535.

PARIDA, A.K. - DAS, A.B. 2005. Salt tolerance and salinity effects on plants: a review. In Ecotoxicology and Environmental Safety, vol. 60, pp. 324-349. DOI:10.1016/j.ecoenv.2004.06.010.

PHILLIPS, J.M. - HAYMAN, D.S. 1970. Improved procedures for clearing roots and staining parasitic and vesicular-arbuscularmycorrhizal fungi for rapid assessment of infection. In Transaction of the British Mycological Society, vol. 55, no. 1, pp. 158-161.

QUEREJETA, J.I. - BAREA, J.M. - ALLEN, M.F. - CARAVACA, F. - ROIDAN, A. 2003. Differential response of $\delta^{13} \mathrm{C}$ and water use efficiency to arbuscular mycorrhizal infection in two aridland woody plant species. In Oecologia, vol. 135, pp. 510-515. DOI: $10.1007 / \mathrm{s} 00442-003-1209-4$.

QUIROGA, M. - GUERRERO, C. - BOTELLA, M.A. BARCELÓ, A.R. - MEDINA, M.I. - ALONSO, F.J. 2000.A tomato peroxidase involved in the synthesis of lignin and suberin. In Plant Physiology, vol. 122, pp. 1119-1127.

ROS-BARCELÓ, A. - GÓMEZ-ROS, L.V. - FERRER, M.A. - HERNÁNDEZ, J.A. 2006. The apoplastic antioxidant enzymatic systeminthewood-forming tissues of trees. In Trees-Structure and Function, vol. 20, no. 2, pp. 145-156. DOI 10.1007/s00468-005-0020-8.

ROS-BARCELÓ, A. 1998. The generation of $\mathrm{H}_{2} \mathrm{O}_{2}$ in the xylemof Zinnia elegans ismediated by an NADPH-oxidase-like enzyme. In Planta, vol. 207, pp. 207-216.

RUIZ-LOZANO, J.M. - AZCÓN, R. 1996. Mycorrhizal colonization and drought stress as factors affecting nitrate reductase activity in lettuce plants. In Agriculture Ecosystem \& Environment, vol. 60, no. 2-3, pp. $175-181$.

RUIZ-LOZANO, J.M. - AZCÓN, R. 2000. Symbiotic efficiency and infectivity of an autochthonous arbuscular mycorrhizal Glomus sp. from saline soils and Glomus deserticola under salinity. In Mycorrhiza, vol. 10, pp. 137-143.

SARAVANAKUMAR, D. - SAMIYAPPAN, R. 2007. ACC deaminase from Pseudomonas fluorescensmediated saline resistance in groundnut (Arachis hypogea) plants. In Journal of Applied Microbiology, vol. 102, pp. 1283-1292.

SCANDALIOS, J.G. - GUAN, L. - POLIDORDS, A.N. 1997. Catalases in plants: gene structure, proprieties, and expression. In SCANDALIOS, J.G. (Ed.) Oxidative stress and the Molecular Biology of Antioxidant Defences. Cold Spring Harbor : New York, pp. 343-406.

SCHELLENBAUM, L. - MÜLLER, J. - BOLLER, T. - WIENKEN, A. - SCHÜEPP, H. 1998. Effects of drought on non-mycorrhizal and mycorrhizal maize: changes in the pools of non-structural carbohydrates, in the activities of invertase and trehalose, and in the pools of amino acids and imino acids. In New Phytologist, vol. 138, no. 1, pp. 59-66. DOI: 10.1046/j.1469-8137.1998.00892.x.

SHARIFI, M. - GHORBANLI, M. - EBRAHIMZADEH, H. 2007. Improved growth of salinity- stressed soybean after inoculation with salt pre-treated mycorrhizal fungi. In Journal of Plant Physiology, vol. 164, no. 9, pp. 1144-1151. DOI:10.1016/j.jplph.2006.06.016.

SHARMA, K.D. - DATTA, K.S. - VERMA, S.K. 1990. Effect of chloride and sulphate type of salinity on some metabolic drifts in chickpea (Cicer arietinum L.). In Indian Journal of Experimental Biology, vol. 28 , pp. 890-892.

SIEVERDING, E. 1991. Vesicular-arbuscular Mycorrhiza Management in Tropical Agrosystems. Eschborn, Germany: GTZ, pp. 371.

SIVRITEPE, N. - SIVRITEPE, H.O. - ERIS, A. 2003. The effects of $\mathrm{NaCl}$ priming on salt tolerance in melon seedlings grown under saline conditions. In Scientia Horticulturae, vol. 97, pp. 229-237.

TABATABAI, M.A. - BREMNER, J.M. 1969. Use of p-nitrophenol phosphate in assay of soil phosphatase activity. In Soil Biology and Biochemistry, vol. 1, no. 4, pp. 301-307.

TANK, N.D. - SARAF, M.S. 2010. Salinity resistant PGPR ameliorates $\mathrm{NaCl}$ stress on tomato plants. In Journal of Plant Interaction, vol. 5, pp. 51-58. DOI: $10.1080 / 17429140903125848$.

YAZICI, I. - TÜRKAN, I. - SEKMEN, A.H. - DEMIRAL, T. 2007. Salinity tolerance of purslane (Portulaca oleracea L.) is achieved by enhanced antioxidative system, lower level of lipid peroxidation and proline accumulation. In Environmental and Experimental Botany, vol. 61, pp. 49-57.

Received: September 4, 2013 